\title{
GESTÃO DE ÁREAS VERDES E SUSTENTABILIDADE: ESTUDO DE CASO A PARTIR DOS INDICADORES DE QUALIDADE AMBIENTAL URBANA
}

\author{
Management of Green Areas and Sustainability: \\ Case Study from Urban Environmental Quality Indicators
}

Juscidalva Rodrigues de Almeida

\section{Resumo}

As Áreas Verdes Urbanas são estruturas ecológicas importantes para a sustentabilidade ambiental das cidades, sendo essenciais para amenizar os efeitos da urbanização, cuja falhas no planejamento interferem na preservação da vegetação. Nesse sentido, este estudo tem por objetivo identificar as Áreas Verdes Urbanas de Cacoal/Rondônia e, a partir dos indicadores ambientais, avaliar o status das respectivas áreas em relação ao número de habitantes e crescimento urbano. Os procedimentos envolveram: revisão bibliográfica, pesquisa de campo e elaboração de material cartográfico por meio de Sistemas de Informações Geográficas (SIGs). Utilizamos indicadores que possibilitam analisar os espaços em estudo de forma qualitativa (espacialização das AVPs, tipologia, condições ambientais e usos sociais das mesmas) e quantitativo (quantidade de AVPs e habitantes). Os resultados demonstram que, nos últimos 10 anos, foram criados 20 bairros novos, totalizando 39, possibilitando a criação de novas Áreas Verdes, somando 24 áreas $\left(476.835,55 \mathrm{~m}^{2}\right)$. No entanto o PAV é estimado em 0,011\% e o IAV em 6,73 $\mathrm{m}^{2}$ por habitantes, assim, Cacoal, com 69.780 habitantes na área urbana, apresenta um índice baixo em relação a valor mínimo de $15 \mathrm{~m}^{2}$ por habitante recomendado pela Associação Brasileira de Arborização Urbana. No que refere às condições ambientais, $64,34 \%$ das Áreas Verdes estão degradadas devido às ações antropogênicas.

Palavras-chave: Planejamento Urbano, Mapeamento, Áreas Verdes, Sustentabilidade.

\begin{abstract}
AвSTRACT
Urban green areas are important ecological structures for environmental sustainability of cities, being essential to mitigate the effects of urbanization, whose failures in planning interfere in the preservation of vegetation. In this sense, this study aims to identify the urban green areas of Cacoal/ Rondônia and, from environmental indicators, to evaluate the status of the respective areas in relation to the number of inhabitants and urban growth. The procedures involved: bibliographic review, field research and preparation of cartographic material through Geographic Information Systems (GISs). We used indicators that allow analyze the areas under study qualitatively (spatialization of Urban Public Green Areas, typology, environmental conditions, and their social uses) and quantitative (quantity of Urban Public Green Areas and inhabitants). The results show that in the last 10 years 20 new neighborhoods were created totaling 39, enabling the creation of new green areas, totaling 24 areas $\left(476,835.55 \mathrm{~m}^{2}\right)$. However, the Percentage of Green Areas (PGA) is estimated at $0.011 \%$ and the Green Areas Index - GAI is $6.73 \mathrm{~m}^{2}$ per inhabitant, thus, Cacoal with 69,780 inhabitants in the urban area, has a low index, in relation to the minimum value of $15 \mathrm{~m}^{2}$ per inhabitant recommended by the Brazilian Association of Urban Afforestation. Regarding environmental conditions, $64.34 \%$ of green areas are degraded due to anthropogenic actions.
\end{abstract}

Keywords: Urban Planning, Mapping, Green Areas, Sustainability. 


\section{INTRODUÇão}

O ambiente urbano, de modo geral, é construído por grande adensamento populacional, bem como infraestruturas que compõem os diversos setores e fatores de desenvolvimento urbano. Entre esses componentes, inclui-se a cobertura vegetal, que tem por função proporcionar melhoria no conforto ambiental das cidades que, no entendimento de Nucci (2001), é um atributo muito importante, porém negligenciado no desenvolvimento das cidades. O desflorestamento originário de um processo de ocupação do solo em área rural e a transição para área urbana constitui um gargalo ao planeamento urbano, o que requer estratégia eficiente para revitalização e preservação da cobertura vegetal na cidade, com base no conceito de sustentabilidade, que visa à continuidade dos aspectos econômicos, sociais, culturais e ambientais para a sociedade (VAN BELLEN, 2006).

É importante lembrar que as cidades estão cada vez mais poluídas, e essa poluição, principalmente no ar e nos rios, pode ser reduzida substancialmente preservando-se a vegetação local, o que atualmente vem ganhando notoriedade, com o reconhecimento dos benefícios que essas Áreas Verdes Urbanas desempenham, sobretudo em regiões de clima quente, como é o caso da cidade de Cacoal-Rondônia, inserida no bioma amazônico.

Visando a sustentabilidade ambiental das cidades, a Ciência Geográfica e outras ciências afins têm buscado compreender a problemática ambiental de áreas urbanas, desde o planejamento, a legislação ambiental, a preservação das Áreas Verdes, aos agentes físicos e antropológicos, que são os causadores das mudanças dos diferentes espaços urbanos (PASQUAL \& FACHINI, 2001; BERTRAND \& BERTRAND, 2007; SAMPAIO, 2009; ANDRADE, 2013).

O município de Cacoal, assim como muitas cidades brasileiras, não possui planejamento adequado para vegetação urbana (BORTOLETO et al., 2006), e nem sempre a legislação é respeitada. A existência de áreas verdes nas cidades é um direito de todos, assegurado pelo Artigo 225 da Constituição Federal (BRASIL, 1988), o qual determina que "todos têm direito ao meio ambiente ecologicamente equilibrado, bem de uso comum do povo e essencial à sadia qualidade de vida", determinação ressaltada na Lei n 10.257 , de 10 de julho de 2001, do Estatuto das Cidades (Brasil, 2001) que garante, em seu artigo $1^{\circ}$, "o bem-estar dos cidadãos e equilíbrio ambiental". Nesse sentido, o Código Florestal Brasileiro (Lei $n^{\circ} 12.727$, de 2012), no disposto à Área de Reserva Legal e Regime de Proteção das Áreas Verdes Urbanas, em seu Artigo 25, "considera Áreas Verdes Urbanas os espaços, públicos ou privados, com predomínio de vegetação, preferencialmente nativa, natural ou recuperada, previstos no Plano Diretor, nas Leis de Zoneamento Urbano e Uso do Solo do Município, indisponíveis para construção de moradias, destinados aos propósitos de recreação, lazer, melhoria da qualidade ambiental urbana, proteção dos recursos hídricos, manutenção ou melhoria paisagística, bem como proteção de bens e manifestações culturais" (BRASIL, 2012).

Nesse contexto, Morero et al. (2007) enfatizam a importância de implementar um planejamento coerente com a disponibilidade dos recursos naturais existentes e demandas humanas, priorizando a preservação das Áreas Verdes na paisagem urbana. Elas são tipos especiais de espaços livres para uso público, entretanto, há Áreas Verdes de uso restrito, seja por ser em área de solo privado, ou para fins ecológicos, cujo elemento fundamental de composição é a vegetação, que satisfaz três objetivos principais: ecológico-ambiental, estético e lazer (LIMA \& AMORIM, 2006).

As Áreas Verdes são essenciais para o bem-estar da população, com finalidade de melhorar a qualidade de vida nas suas funções ecológicas, sociais, educacionais e psicológicas (SOUZA et al., 2014), além de outros benefícios, tais como proteção contra ação dos ventos, diminuição da poluição sonora, neutralização do excesso de dióxido de carbono, influência no balanço hídrico, atenuação da temperatura e amortização do impacto das chuvas, proporcionando conforto ambiental (PASQUAL \& FACHINI, 2001a).

A manutenção das Áreas Verdes é extremamente importante para que possam cumprir plenamente suas funções (CAPORUSSO \& MATIAS, 2008). A criação de novas Áreas Verdes possibilita a conservação de valores visuais ou paisagísticos, recreativos e ambientais da cidade, tanto dos bairros centrais, quanto das áreas periféricas, influenciando no conforto climático, com amortização da temperatura. 
Para entender a dinâmica do desenvolvimento das Áreas Verdes na cidade de Cacoal, realizou-se estudo de caso, cujo objetivo esteve pautado na qualidade de vida pela presença de tais espaços. No entanto, essas Áreas Verdes passaram por uma redução expressiva, devido ao crescimento desordenado da cidade para a implantação de projetos de expansão urbana, ocorridos entre os anos de 2000 e 2016, em direção a territórios de pastagens e florestas nativas. Essa ocupação motivou o desflorestamento de extensas Áreas Verdes para construções de moradias, especialmente em Áreas de Preservação Permanente (DE ALMEIDA, 2016).

A abordagem da pesquisa, dentro de uma perspectiva científica, pautou-se nos indicadores ambientais já utilizados em outros estudos e em novos indicadores, que foram estruturados na categoria elementos naturais, seguindo recomendações dos Ministérios das Cidades e Meio Ambiente (BRASIL, 2011; VAN BELLEN, 2006), na formação e avaliação dos indicadores, propostos especificamente para Áreas Verdes Urbanas.

Dessa forma, teve-se como propósito identificar as Áreas Verdes Urbanas de Cacoal e, a partir dos indicadores ambientais, avaliar o status das respectivas áreas em relação ao número de habitantes e crescimento urbano. Portanto, foram utilizados os indicadores: cobertura vegetal, distribuição espacial, pressão antrópica sobre Áreas Verdes, e Áreas Verdes utilizáveis, dos quais foram obtidos as percentagens e índices das Áreas Verdes públicas urbanas em relação ao número de habitantes, distribuição e extensão territorial da cidade, intentando subsidiar o planeamento da paisagem urbana de Cacoal.

\section{Metodologia}

\subsection{Caracterização da Área de estudo}

A área de estudo está localizada no perímetro urbano do município de Cacoal, que fica ao sul do Estado de Rondônia, a $470 \mathrm{~km}$ da capital Porto Velho; sua latitude é $11^{\circ} 26^{\prime} 19$ sul e longitude $61^{\circ} 26^{\prime} 50$ oeste (Figura 1).
O município foi criado em 1977, possui $3.805,5 \mathrm{~km}^{2}$, representando $1,6 \%$ do estado. Já a área urbana representava $16,7 \mathrm{~km}^{2}$, segundo o IBGE (2010), com o crescimento acelerado, nos últimos anos, esses dados foram atualizados pela Secretaria Municipal de Planejamento (SEMPLAN, 2016), vindo a contabilizar $40 \mathrm{~km}^{2}$ de área urbana oficial.

\subsection{Procedimentos metodológicos}

A coleta e processamento dos dados foram realizados usando Sistemas de Informações Geográficas (SIGs) da área urbana, mapa de zoneamento e imagens do Satélite Landsat 8, sensor OLI do Instituto Nacional de Pesquisas Espaciais - INPE, órbita 230 - 68 registradas em 12 de agosto de 2016, Sistema de Projeção Geodésico (SIRGAS 2000), Zona 20 sul, (66-60W), as quais foram processadas pelo software ArcGis 10.1 para identificação visual das Áreas Verdes da cidade.

Ainda, utilizaram-se os dados censitários do Instituto Brasileiro de Geografia e Estatística (IBGE, 2010, 2015) para levantamento dos setores censitários e número de habitantes, além dos registos de imagens em campo, informações do Plano Diretor Municipal (PMC, 2006) e banco de dados integrados de 2000 a 2016, da Secretaria Municipal de Planejamento Urbano (SEMPLAN, 2016), os quais possibilitaram analisar o status das Áreas Verdes na paisagem urbana de Cacoal (Figura 2).

Considerando a multidimensionalidade dos processos de desenvolvimento urbano de Cacoal, as análises de caráter quantitativos e qualitativos buscaram estabelecer as relações entre as Áreas Verdes Urbanas e números de habitantes, permitindo identificar e mapear as Áreas Verdes da cidade.

Para o mapeamento e classificação das Áreas Verdes Urbanas, observou-se os elementos importantes contidos no conceito de Áreas Verdes, tais como: I) a localização em área urbana; II) a predominância de cobertura vegetal em solo livre de edificações ou coberturas impermeabilizantes, e III) funções ecológicas, analisando o grau de interferência das ações antrópicas e planejamento urbano, para facilitar a execução da pesquisa em campo. 


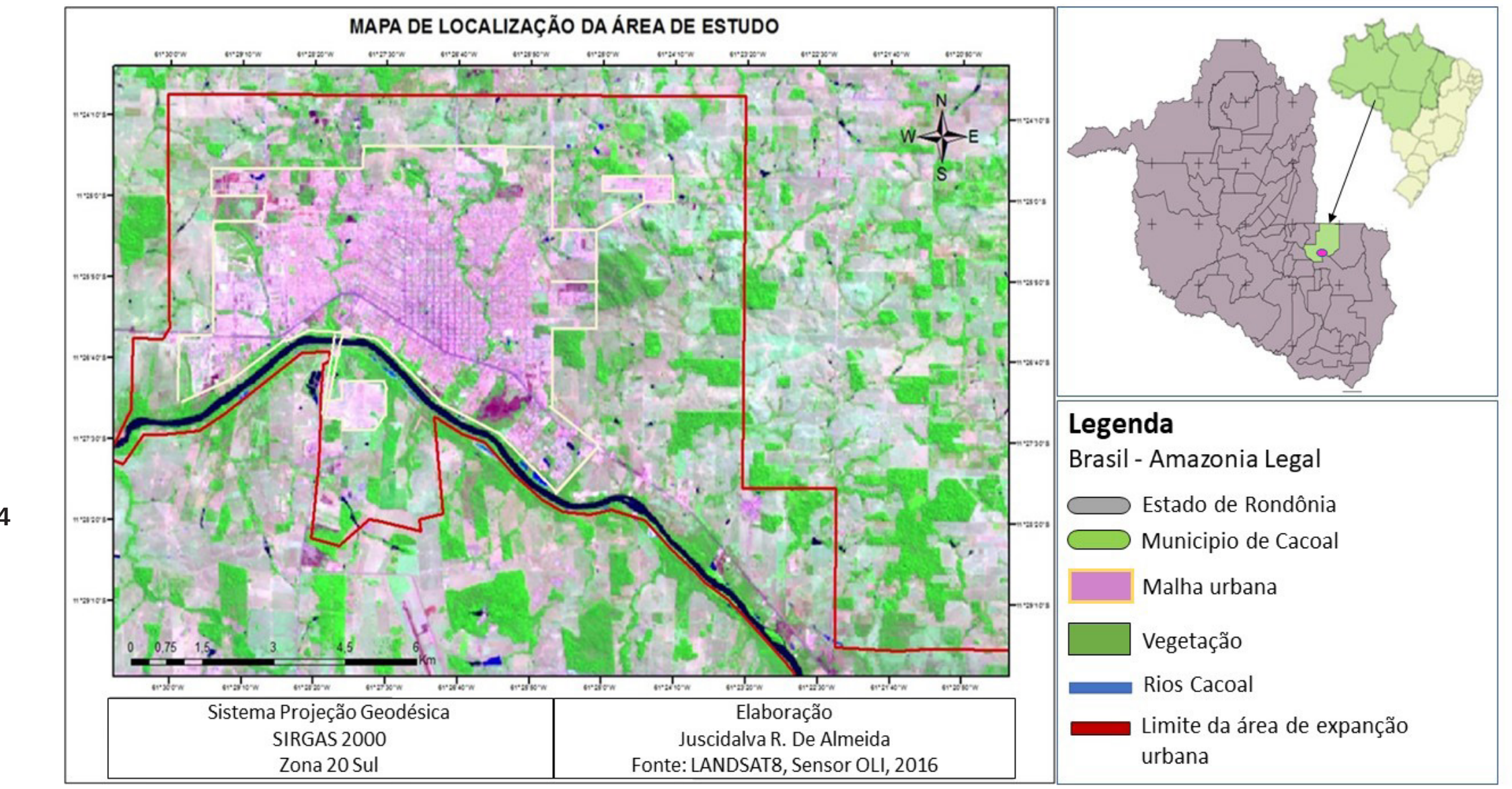

Figura 1 - Área de estudo no Município de Cacoal-RO.

Fonte: Elaborado pelo autor, 2016.

Quanto à representação dos valores numéricos com relação aos espaços em análise, utilizou-se 6 (seis) indicadores de Áreas Verdes, sendo (três) propostos por (NUCCl, 2001; CAPORUSSO \& MATIAS, 2008) e três elaborados pelo (próprio autor), conforme o (Quadro 1), estruturados dentro das categorias dos elementos naturais, como as características do clima, uso e ocupação do solo, vegetação, desflorestamento e funções ecológicas, considerando as recomendações dos Ministérios das Cidades e do Meio Ambiente (BRASIL, 2011; VAN BELLEN, 2006), os quais permitiram as obtenções dos índices. 
Quadro 1 - Relação dos indicadores de áreas verdes urbanas, conforme suas fórmulas e referências

\begin{tabular}{l|c|l}
\multicolumn{1}{c|}{ Descrição dos indicadores } & Fórmulas & \multicolumn{1}{c}{ Referências } \\
\hline Percentual de Áreas Verdes - PAV & PAV $=\frac{\text { Áreas Verdes }\left(m^{2}\right)}{\text { Área do Bairro }}$ & $\begin{array}{l}\text { NUCCI (2001); CAPORUSSO \& MATIAS } \\
(2008)\end{array}$ \\
\hline Indicador de Áreas Verdes - IAV & IAV $=\frac{\text { Total de Áreas Verdes }\left(\mathrm{m}^{2}\right)}{\text { Número de habitantes }}$ & $\begin{array}{l}\text { NUCCI (2001); CAPORUSSO \& MATIAS } \\
(2008)\end{array}$ \\
\hline $\begin{array}{l}\text { Indicador de Áreas Verdes por Bairro - } \\
\text { IAVPB }\end{array}$ & IAVPB $=\frac{\text { Total Áreas Verdes } / \text { Bairros }\left(\mathrm{m}^{2}\right)}{\mathrm{N}^{\circ} \text { habitantes } / \text { bairros }}$ & CAPORUSSO \& MATIAS (2008) \\
\hline $\begin{array}{l}\text { Indicador de Distribuição Espacial das } \\
\text { Áreas Verdes - IDEAV }\end{array}$ & IDEAV $=\frac{\text { Total Áreas Verdes } / \text { Região }\left(\mathrm{m}^{2}\right)}{\mathrm{N}^{\circ} \text { habitantes } / \text { região }}$ & Próprio autor \\
\hline $\begin{array}{l}\text { Indicador de Pressão Antrópica sobre Áreas } \\
\text { Verdes - IPAAV }\end{array}$ & IPAAV $=\frac{\text { Total Áreas V. Degradadas }\left(\mathrm{m}^{2}\right)}{\text { Total Áreas Verdes Urbanas }}$ & Próprio autor \\
\hline Indicador de Áreas Verdes Utilizáveis - IAVU & IAVU $=\frac{\text { Total Áreas Verdes Utilizáveis }\left(\mathrm{m}^{2}\right)}{\mathrm{N}^{\circ} \text { habitantes }}$ & Próprio autor \\
\hline
\end{tabular}

Fonte: Elaborado pelo autor, 2016.

Para esta investigação, fez-se uso desse conjunto de indicadores na intenção de obter um disgnóstico mais completo da real situação sobre a vegetação urbana de Cacoal, particularmente as "Áreas Verdes" estudas até então, com uso dos indicadores (PAV, IAV e IAVPB), sendo assim, foi necessário criar novos indicadores (IDEAV, IPAAV e IAVU) para atender ao objetivo do estudo. As aplicações dos indicadores de Áreas Verdes propostos procederam-se a partir da avaliação espacial - identificação da existência e distribuição dessas zonas na cidade de Cacoal, seguidos das observações e coleta de dados em campo, por meio de formulário específico para avaliar as condições das Áreas Verdes, com o auxílio de mapa cartográfico da (SEMPLAN, 2016).

No que diz respeito à avaliação dos índices, foram consideradas, para os cálculos, somente as Áreas Verdes públicas, localizadas na zona urbana, ligadas ao uso direto da população residente e com fins ecológicos. À vista disso, o Percentual de Áreas Verdes (PAV) es- tabeleceu a relação e divisão entre as Áreas Verdes remanescentes e área urbanizada (bairros) para obtenção da percentagem. Todavia, o Índice de Áreas Verdes (IAV) foi obtido a partir do cálculo de divisão entre o somatório das Áreas Verdes da cidade e número de habitantes da cidade, com base na metodologia de Nucci (2001); Caporusso \& Matias, (2008); Lucon et al., (2013), cartografia do perímetro urbano, população por setor censitário do (IBGE, 20102015) e banco de dados da (SEMPLAN, 2016).

O indicador de Áreas Verdes por Bairro (IAVPB) avaliou as condições ambientais das Áreas Verdes com base no Índice da Evolução desses locais, relativo ao crescimento urbano no período de 2000 a 2016, consistindo na somatória das Áreas Verdes por bairro e dividido pelo número de habitantes do bairro. Enquanto o Indicador de Distribuição Espacial das Áreas Verdes (IDEAV) analisou o percentual de distribuição espacial das Áreas Verdes por regiões urbanas. 
Outrossim, o Indicador de Pressão Antrópica sobre Áreas Verdes (IPAAV) avaliou o índice de degradação ou perda da cobertura vegetal urbana, originados pelas atividades humanas, e constituiu na divisão entre o total de áreas degradadas pelo total de Áreas Verdes Urbanas. Já o indicador de Áreas Verdes Utilizáveis (IAVU) teve o índice obtido da somatória das áreas de praças e parques totalmente utilizáveis dividido pelo número de habitantes locais. A relevância das Áreas Verdes Urbanas na cidade, baseada nos indicadores estabelecidos, possibilitou a identificação e análise das condições ambientais das Áreas Verdes, garantindo proposição de alternativas do desenvolvimento ambiental sustentável da cidade.

\section{Resultados}

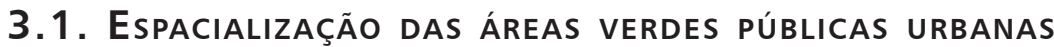
da da vegetação natural que foi suprimida ao longo do processo histórico evolutivo de ocupação do solo, principalmente nos bairros mais antigos, que caracterizam o centro da cidade, devendo-se atentar para as alterações da quantidade de Áreas Verdes Urbanas disponíveis por habitante. A cidade apresentou um aumento da população, ocorrendo uma significativa ampliação do perímetro urbano de $16 \mathrm{~km}^{2}$ para $40 \mathrm{~km}^{2}$ aproximadamente (Figura 1), com criação de novos bairros, sendo a maioria com presença de Áreas Verdes (Figura 2), estando em harmonia com a legislação e projeção do Plano Diretor Municipal.

O mapeamento das Áreas Verdes permitiu indicar que estão concentradas nos bairros mais afastados do centro da cidade. Esses bairros foram criados nos últimos 10 anos e grande parte localizam-se na região oeste, que apresenta a maior concentração e índices de Áreas Verdes, com destaque para o bairro Vila Verde (Green-ville), contudo, na região central, há carência desses espaços (Figura 2). A cidade possui 24 Áreas Verdes, correspondendo a cerca de $476.835 \mathrm{~m}^{2}$. As dimensões $\left(\mathrm{m}^{2}\right)$ das Áreas Verdes, condições ambientais e o número de habitantes constituem-se na avaliação dos indicadores, os resultados podem ser observados na (Tabela 1) de forma mais detalhada.

\subsection{Avaliação dos indicadores das Áreas verdes uRbanas de CACOAL}

Os resultados do estudo apontam que a cidade de Cacoal era formada por 54 bairros e, com a reorganização do ordenamento urbano, em 2012, houve uma redução para 39 bairros, que representam 40.883.841,43 $\mathrm{m}^{2}$ de extensão geográfica. Ao todo, foram identificadas 24 Áreas Verdes (AV), representando os $476.835 \mathrm{~m}^{2}$ de Áreas Verdes públicas, metragem que $(\div)$, com as áreas dos bairros, obtém um percentual de Áreas Verdes (PAV) de 0,011\%. De 15 bairros, não foi possível obter os percentuais de Áreas Verdes, mas o bairro Nova Esperança apresenta o percentual de $40,84 \%$ - único bairro antigo com maior cobertura vegetal na cidade (Tabela 1).

Ao todo, registrou-se um total de $476.835 \mathrm{~m}^{2}$ de Áreas Verdes públicas e uma população urbana estimada em 69.782 habitantes. Conforme esses valores, o Índice de Áreas Verdes da cidade corresponde a $6,83 \mathrm{~m}^{2}$ por habitante (Tabela 2 ), inferior ao valor estabelecido pela Associação Brasileira de Arborização Urbana (SBAU, 1996), a qual recomenda $15 \mathrm{~m}^{2}$ de Áreas Verdes por habitante, sobretudo em parques.

\subsection{Distribuição espacial das Áreas Verdes}

No intuito de buscar uma melhor compreensão da distribuição das Áreas Verdes na cidade de Cacoal, analisou-se, a partir da aplicação do Indicador de Distribuição Espacial das Áreas Verdes (IDEAV), o percentual de distribuição das áreas por regiões urbanas. Os resultados demonstram que, das cinco regiões avaliadas, a que obteve o maior percentual de Áreas Verdes foi a região oeste, com 3,59\% (Tabela 2), composta pelos bairros: Nova esperança, Cristal Arco-íris, Alvorada, Josino Brito, Jardim Bandeirante, Conjunto Haley, Vista Alegre, Vila Verde, Parque dos Lagos, Habitar Brasil, Sociedade Bela Vista, Jardim Itália e Bairro Fortaleza. 


\section{MAPEAMENTO DE ÁREAS VERDES PÚBLICAS URBANAS DE CACOAL-RO}

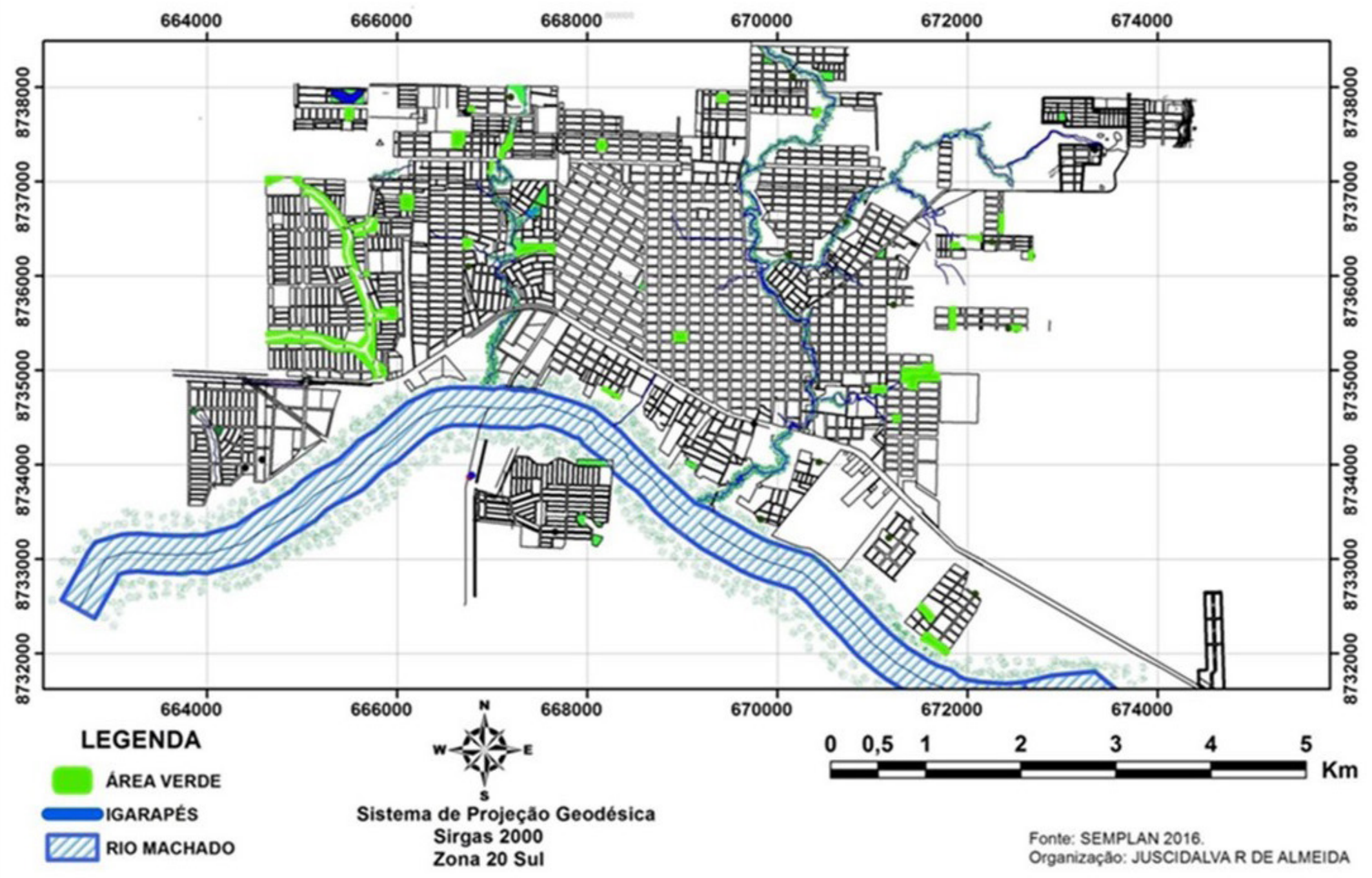

Figura 2 - Áreas Verdes públicas urbanas de Cacoal.

Fonte: SEMPLAN, elaborado pelo autor, 2016. 
Tabela 1 - Características de percentagem e índices de Áreas Verdes da cidade de Cacoal em relação aos levantamentos dos bairros, Áreas Verdes e número de habitantes

\begin{tabular}{|c|c|c|c|c|c|c|}
\hline $\mathbf{N}^{\circ}$ & Bairros & $\begin{array}{l}\text { Área do Bairro } \\
\qquad\left(m^{2}\right)\end{array}$ & $\begin{array}{l}N^{\circ} \text { de Habitantes } \\
\text { por Bairros }\end{array}$ & $\begin{array}{l}\text { Áreas Verdes } \\
\text { por Bairro }\left(\mathrm{m}^{2}\right)\end{array}$ & PAV \% por Bairro & IAV/hab. $\left(m^{2}\right)$ \\
\hline 1 & Centro & 1019508,08 & $3.302,00$ & $9.604,00$ & $0,94 \%$ & 2,91 \\
\hline 3 & Jardim Clodoaldo & 1287220,35 & $5.689,00$ & 0,00 & $0,00 \%$ & 0,00 \\
\hline 4 & Novo Cacoal & 803173,71 & $4.378,00$ & $1.036,00$ & $0,13 \%$ & 0,23 \\
\hline 7 & Conjunto Haley & 139139,73 & $3.576,00$ & 0,00 & $0,00 \%$ & 0,00 \\
\hline 8 & Cristal do Arco-íris & 222393,28 & $1.554,00$ & 0,00 & $0,00 \%$ & 0,00 \\
\hline 9 & Floresta & 523389,50 & $2.606,00$ & 0,00 & $0,00 \%$ & 0,00 \\
\hline 10 & Incra & 543341,15 & 931,00 & 0,00 & $0,00 \%$ & 0,00 \\
\hline 14 & Liberdade & 1237907,44 & $2.850,00$ & 0,00 & $0,00 \%$ & 0,00 \\
\hline 15 & Res. Parque Brizon & 946935,73 & $2.392,00$ & $7.088,22$ & $0,75 \%$ & 2,96 \\
\hline 16 & Santo Antônio & 651428,00 & $1.470,00$ & $1.525,83$ & $0,23 \%$ & 1,03 \\
\hline 17 & Saúde & 258660,60 & 840,00 & 0,00 & $0,00 \%$ & 0,00 \\
\hline 18 & Sociedade Bela Vista & 488916,12 & $1.700,00$ & $4.367,11$ & $0,89 \%$ & 2,56 \\
\hline 19 & Josino Brito & 465032,83 & $2.200,00$ & $4.531,86$ & $0,97 \%$ & 2,05 \\
\hline 20 & Colina Verde & 1003094,34 & 1. 372 & $1.059,72$ & $0,11 \%$ & 0,77 \\
\hline 21 & Teixeirão & 1339176,98 & $4.800,00$ & 975,00 & $0,07 \%$ & 0,20 \\
\hline 22 & Village do Sol & 1674386,59 & $5.900,00$ & 0,00 & $0,00 \%$ & 0,00 \\
\hline
\end{tabular}




\begin{tabular}{|c|c|c|c|c|c|c|}
\hline 26 & Parque G. Jerônimo Sant. & 1195873,97 & 10,00 & 0,00 & $0,00 \%$ & 0,00 \\
\hline 27 & Vila Romana & 1764456,35 & 70,00 & 0,00 & $0,00 \%$ & 0,00 \\
\hline 28 & Jardim São Pedro & 856747,67 & 10,00 & 0,00 & $0,00 \%$ & 0,00 \\
\hline 29 & Habitar Brasil & 186782,02 & 900,00 & $14.945,09$ & $8,00 \%$ & 16,60 \\
\hline 30 & Jardim Europa & 801878,11 & 200,00 & $17.700,54$ & $2,21 \%$ & 88,50 \\
\hline 31 & Parque Alvorada & 252994,93 & 100,00 & $17.296,74$ & $6,84 \%$ & 172,96 \\
\hline 32 & Parque Fortaleza & 167274,20 & $1.500,00$ & $7.031,72$ & $4,20 \%$ & 4,68 \\
\hline 33 & Parques dos Lagos & 1000000,00 & 500,00 & $7.724,24$ & $0,77 \%$ & 15,44 \\
\hline 34 & Parque Alphaville & 991124,84 & 230,00 & $5.377,10$ & $0,54 \%$ & 23,37 \\
\hline 35 & Res. Alpha Parque & 1000000,00 & $1.800,00$ & $9.134,96$ & $0,91 \%$ & 5,07 \\
\hline 36 & Morada do Bosque & 1107013,18 & 90,00 & $8.538,92$ & $0,77 \%$ & 94,87 \\
\hline 37 & Residencial Embratel & 999759,46 & 400,00 & $13.743,59$ & $1,37 \%$ & 34,35 \\
\hline 38 & Sete de Setembro & 2021656,00 & 750,00 & $11.464,23$ & $0,57 \%$ & 2,76 \\
\hline 39 & Buritis & 7271915,50 & 10,00 & $1.494,48$ & $0,02 \%$ & 149,44 \\
\hline Total & 39 bairros & $40.883 .841,43$ & $69.782,00$ & $476.835,55$ & $83,07 \%$ & 1281,69 \\
\hline \multicolumn{5}{|c|}{ * Resultado do PAV e do IAV/HAB considerando a área urbana ocupada } & 0,011 & $6,83 \mathrm{~m}^{2}$ \\
\hline
\end{tabular}

PAV-Percentual de Áreas Verdes; lav-Índice de Áreas Verdes; Hab-habitante.

Fonte: Elaborado pelo autor, 2016.

Tabela 2 - Percentual de Áreas Verdes por regiões urbanas de Cacoal

\begin{tabular}{c|c|c|c}
\hline Regiões & $N^{\circ}$ de Bairros & Área dos bairros $\left(m^{2}\right)$ & Áreas Verdes por airro $\left(m^{2}\right)$ \\
\hline Leste & 10 & 9396034,07 & $88.327,40$ \\
\hline Oeste & 14 & 9148141,86 & $328.530,10$ \\
\hline Norte & 04 & 4932352,58 & $27.091,37$ \\
\hline Sul & 06 & 12834011,45 & $22.246,68$ \\
\hline Centro & 05 & 4573301,47 & 0,55 \\
\hline Total & 39 & $40.883841,43$ & 0,23 \\
\hline
\end{tabular}

Legenda: PAV-Percentual de Áreas Verdes.

Fonte: elaborado pelo autor, 2016. 
Por sua vez, a região leste, com PAV de $0,94 \%$, é formada pelos bairros Colina Verde, Alpha Parque, Alphaville, Embratel, Teixeirão, Jardim Eldorado, Floresta, Incra, Vilage do Sol e Saúde. Já a região norte tem $0,55 \%$ de Áreas Verdes, distribuídas entre os bairros Sete de Setembro, Morada do Bosque, São Pedro e Parque Brizon. A região sul é a mais carente dessas zonas, com apenas $0,17 \%$, sendo composta pelos bairros: Liberdade, Santo Antônio, Jardim Europa, Vila Romana, Industrial e Buritis. Destaca-se que, na região central, composta pelos bairros Centro, Jardim Clodoaldo, Princesa Izabel, Novo Horizonte e Novo Cacoal, o PAV é 0,23\%, o que é preocupante, já que essa região apresenta a maior concentração de habitantes.

\subsection{Condições ambientais das Áreas verdes (com RELAÇÃO AO DESENVOLVIMENTO URBANO)}

O resultado do Indicador de Áreas Verdes por Bairro (IAVPB) demonstrou que, de 2005 a 2010, foram criados nove (09) bairros, dos quais, $80 \%$ têm Áreas Verdes. Por seu turno, entre 2010 e bairros, dos quais $90 \%$ têm presença de Áreas Verdes. Os Percentuais de Áreas Verdes por Setores Censitários (Tabela 2) permitem observar a situação real da paisagem urbana no tocante às Áreas Verdes e, assim, a avaliação do IAVPB em relação ao crescimento urbano. Verificou-se os índices de Áreas Verdes de acordo com o número de habitantes por bairros e os resultados não foram positivos para o período de 2000-2010, consoante a (Figura 3).

Entre 2000 e 2010, o bairro Nova Esperança apresentou o maior índice - 59,59 - de Áreas Verdes por habitante. Não obstante, entre 2010 e 2016, o cenário mudou de forma positiva, obtendo maiores índices nos bairros Vila Verde (Greenville), com 499,75 m²; Parque Alvorada, com 172,96 m²; Buritis, 149,44 m²; Morada do Bosque, $94,87 \mathrm{~m}^{2}$; Jardim Europa, com 88,50 $\mathrm{m}^{2}$; e Nova Esperança, 59,59 $\mathrm{m}^{2}$, como demostra a (Figura 4).

Esses bairros foram criados recentemente e encontram-se com mais de $80 \%$ dos lotes vazios, "sem construções de moradias", especialmente os bairros Vila Verde, Buritis, Parque Alvorada, Morada do Bosque, Jardim Europa, Jardim Eldorado, Embratel e Parque Alpha-

ville. Doze bairros apresentaram índices de Áreas Verdes correspondentes aos valores entre $0,20 \mathrm{~cm}$ e 5,07. Quanto aos demais, não se pôde obter o índice em razão da ausência de Áreas Verdes, as vegetações foram suprimidas para dar espaço às construções de moradias. Os bairros onde estão concentradas as Áreas Verdes utilizáveis, destinadas ao lazer da população, são os mais antigos da cidade.

\subsection{Nível de pressões antrópicas sobre Áreas verdes}

O crescimento acelerado elevou o aumento da expansão urbana de Cacoal e o processo de transição de área rural em urbana contribuiu para a elevação do índice de degradação da vegetação urbana. Esse Índice foi obtido por meio do Indicador de Pressões Antrópicas (IPAAV) sobre Áreas Verdes, usando-se as seguintes metragens e fórmula:

\section{IPAAV $=\underline{\text { Total de Áreas Verdes degradadas }} \quad \underline{306.796,24 \mathrm{~m}^{2}}=64,34 \%$ Total de Áreas Verdes urbanas $476.835,55 \mathrm{~m}^{2}$}

Por meio dessa fórmula, detectou-se que, dos 476.835,55 $\mathrm{m}^{2}$ de Áreas Verdes Urbanas, 64,34\% estão degradadas, devido às intensas atividades de origem antropogênica, tais como desflorestamento, queimadas, assoreamentos de mananciais e construções de moradias. As Áreas Verdes nativas representam apenas 35,66\%, e parte dessas localizam-se no bairro Vila Verde "Greenville" (Tabela 1, Figura 2), que possui a maior cobertura de Área Verde Urbana da cidade, com 26 Áreas Verdes, que compreendem um total de $125.939,34 \mathrm{~m}^{2}$, localizada na região Oeste da cidade.

Faz-se mister explicar que são Áreas de Proteção Ambiental (APA) para fins ecológicos, não edificadas, porém, 90\% das Áreas Verdes estão degradadas, em estado de sucessão ecológica secundária, "áreas que anteriormente foram modificadas por agentes externos e ocupadas por outra comunidade" resultado da forte pressão antrópica sofrida, tais como desflorestamento para formação de pastagens e criação de gado, apenas $10 \%$ é composta com floresta nativa. Algumas áreas mais degradadas foram cercadas e feito 0 reflorestamento com espécies nativas da região (Figura 5). 


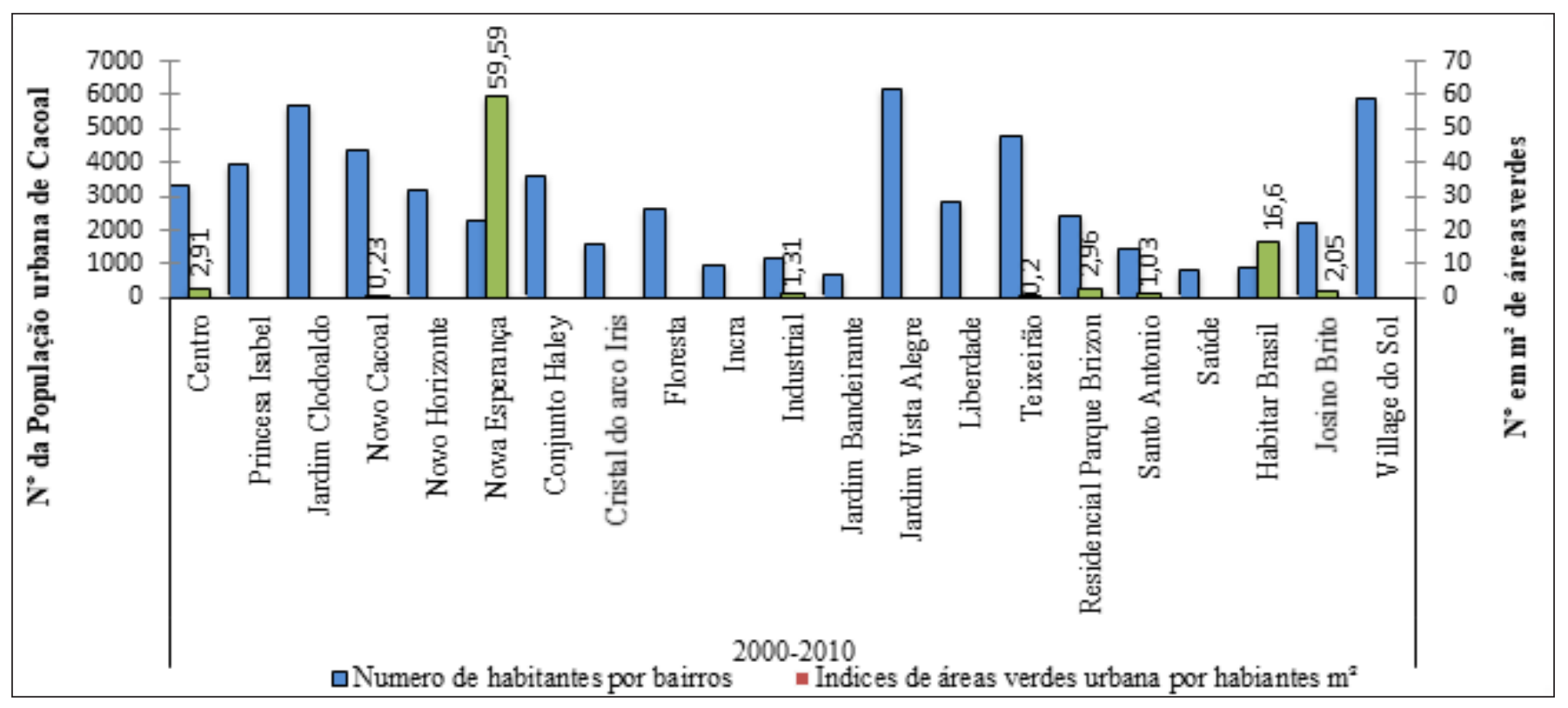

Figura 3 - Índice de Áreas Verdes por Setores Censitários da cidade de Cacoal (2000-2010).

Fonte: elaborado pelo autor, 2016

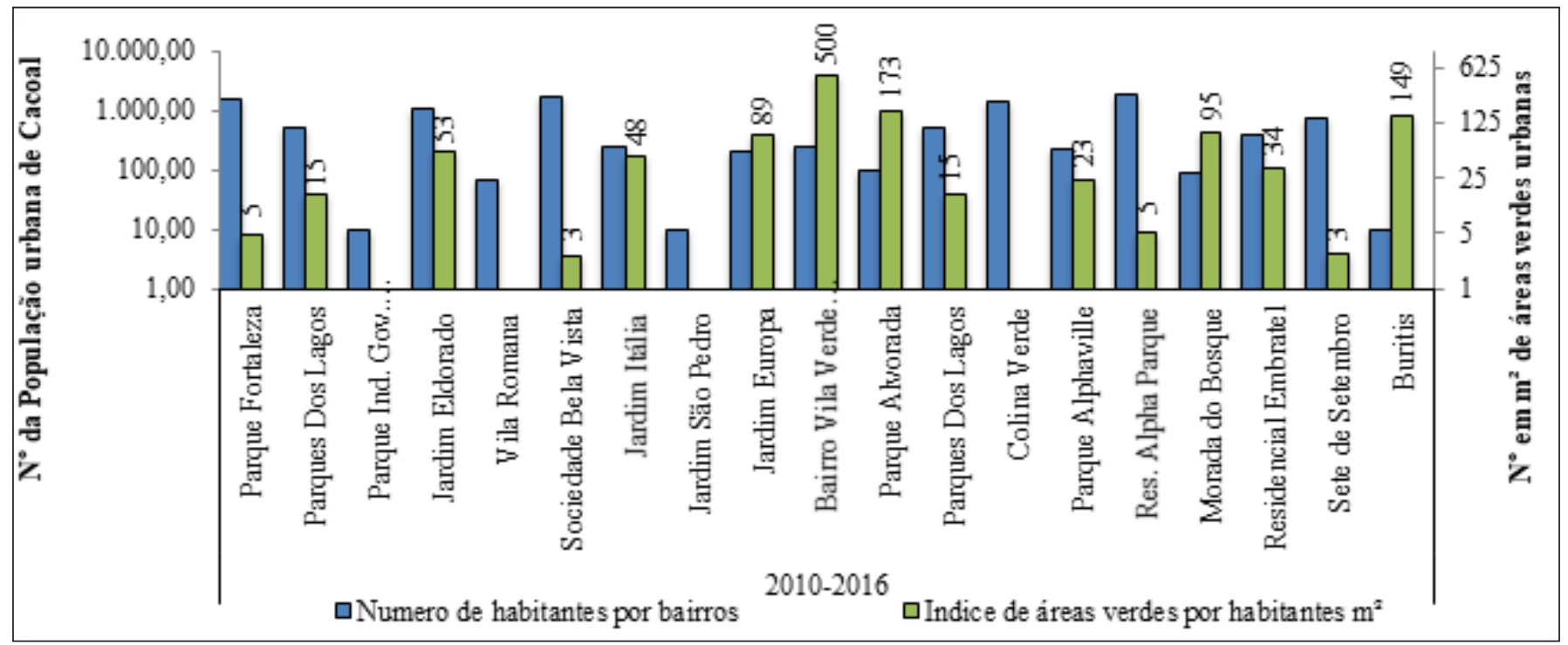

Figura 4 - Índice de Áreas Verdes por Setores Censitários da cidade de Cacoal (2010-2016).

Fonte: elaborado pelo autor, 2016. 


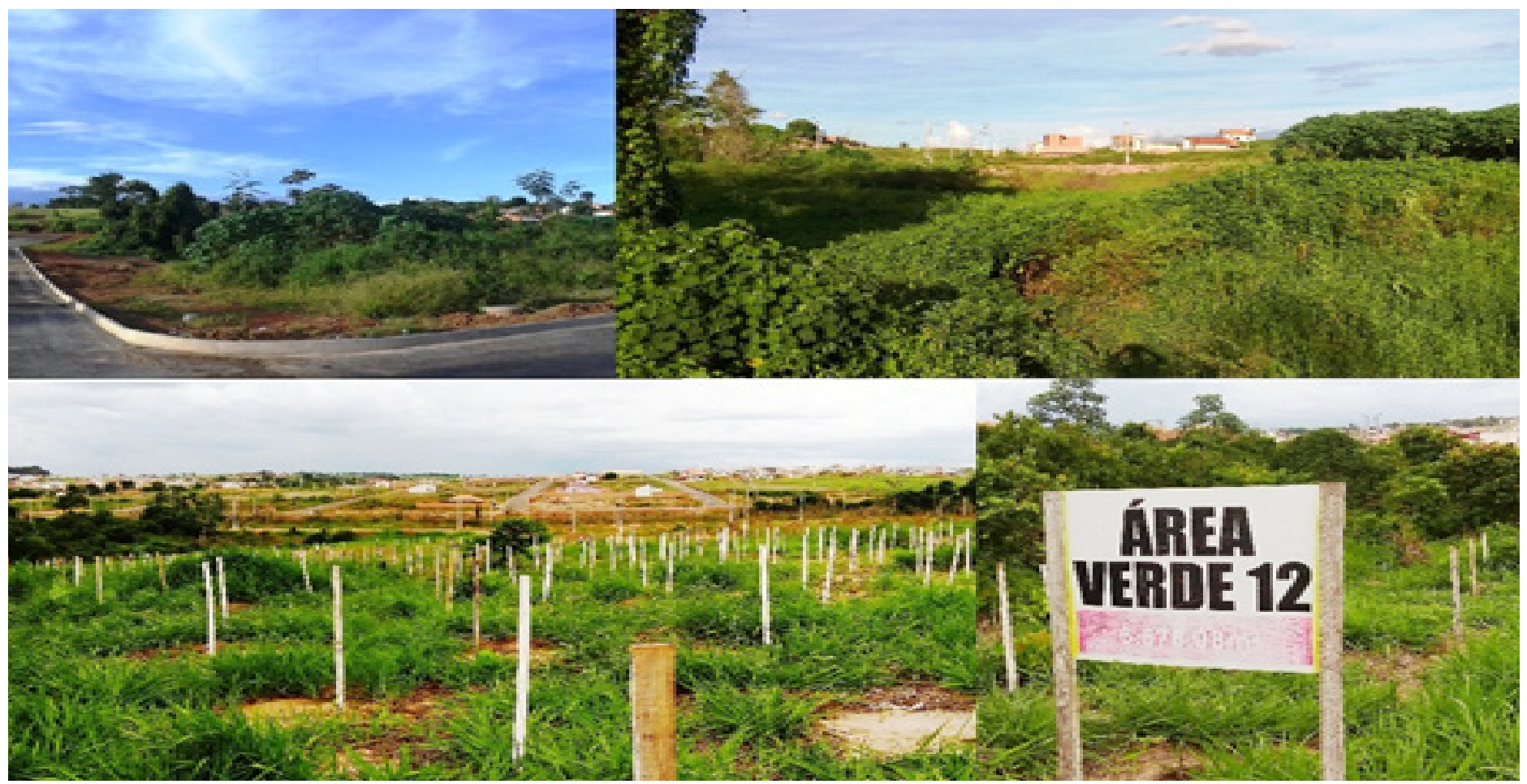

Figura 5 - Vila Verde - áreas verdes nativas e em reflorestamento. Fonte: elaborado pelo autor, 2016

O bairro Vila Verde é o único que apresenta placas de identificação das Áreas Verdes presentes, com orientação sobre preservação ambiental, proibindo abusos, sob pena de multas, em conformidade com a legislação vigente. No entanto, o processo de degradação ambiental comprometeu as Áreas de Preservação Permanente (APPs) e, conseguintemente, o assoreamento de mananciais.

\section{6. Áreas verdes utilizÁveis}

Foram registradas seis Áreas Verdes Urbanas com potencial de utilização pela população cacoalense por apresentarem funções ecológicas, paisagísticas e recreativas, proporcionando melhoria da qualidade estética, funcional e ambiental da cidade, dotadas de vegetação, mas são áreas edificadas, com implantação de equipamentos para fins recreativos, desportivos, assentos, quiosque e lago. Das seis áreas utilizáveis (Tabela 3), o Parque Sabiá é o que apresenta maior percentual, 40,84\%, quando comparadas as metragens do parque com a área do bairro. Também se constatou que o índice de Área Verde por habitante é $59,59 \mathrm{~m}^{2}$, considerando os 2.270 habitantes do bairro Nova Esperança, sendo, portanto, a maior área verde com funções ecológicas e recreativas da cidade. Essas Áreas Verdes são consideradas de domínio público, asseguradas pelo Art. $8^{\circ}, \S 1^{\circ}$, da Resolução CONAMA Nº 369 (BRASIL, 2006). 
Tabela 3 - Áreas Verdes com potencial de uso coletivo da população, avaliadas a partir dos levantamentos de bairros, das Áreas Verdes existentes e suas metragens, tipologia e número de habitantes

\begin{tabular}{|c|c|c|c|c|c|c|c|}
\hline $\mathrm{N}^{\circ}$ & Bairros & $\begin{array}{l}\text { Área do bairro } \\
\left(\mathrm{m}^{2}\right)\end{array}$ & $\begin{array}{c}\text { No de } \mathrm{Hab} / \\
\text { Bairros }\end{array}$ & $\begin{array}{l}\text { Tipologia de } \\
\text { Área Verde }\end{array}$ & $\begin{array}{l}\text { Áreas Verdes/ } \\
\text { bairro }\left(\mathrm{m}^{2}\right)\end{array}$ & PAV (\%) & $\begin{array}{l}\text { IAV/Hab } \\
\left(\mathrm{m}^{2}\right)\end{array}$ \\
\hline 1 & Centro & 1019508,08 & $3.302,00$ & Praça G. Jorge & $9.604,00$ & $0,94 \%$ & 2,91 \\
\hline 2 & Novo Cacoal & 803173,71 & $4.378,00$ & Praça & $1.036,00$ & $0,13 \%$ & 0,23 \\
\hline 3 & Nova Esperança & 331222,13 & $2.270,00$ & Parque Sabiá & $135.285,00$ & $40,84 \%$ & 59,59 \\
\hline 4 & Parque Brizon & 946935,73 & $2.392,00$ & Praça & $7.088,22$ & $0,75 \%$ & 2,96 \\
\hline 5 & Teixeirão & 1339176,98 & $4.800,00$ & Praça & 975,00 & $0,07 \%$ & 0,20 \\
\hline 6 & Parque Fortaleza & 167274,20 & 1.500 & Praça de Esporte & $7.031,72$ & 4,20 & 4,68 \\
\hline Total & 06 & 5409168,94 & $18.842,00$ & & $178.720,48$ & & \\
\hline
\end{tabular}

Legenda: PAV-Percentual de Áreas Verdes; IAV-Índice de Áreas Verdes; Hab-habitante. Fonte: Elaborado pelo autor, 2016.

Contudo, apesar de as outras cinco áreas apresentarem boa potência de uso pela população, os índices são extremamente baixos em relação à recomendação da Associação Brasileira de Arborização Urbana (SBAU, 1996), que estabelece $15 \mathrm{~m}^{2}$ de áreas verdes por habitante, principalmente em parques e praças. Em geral, as Áreas Verdes não utilizáveis representam $83,07 \%$, a maioria dessas áreas não está identificada como área de proteção ambiental. Logo, as áreas com potencial utilizável representam apenas $17 \%$, são parques e praças que necessitam de revitalização, com plantio de árvores, levando em conta as características botânicas das espécies e as normas técnicas. E, como ilustração das principais Áreas Verdes, destaca-se o Parque Sabiá (Figura 6).

Localizado no bairro Novo Esperança, o Parque Ecológico Sabiá é uma Área Verde que tem função ecológica, lazer e desportiva, com extensão de 135.285,00 $\mathrm{m}^{2}$, composto de espécies arbóreas, gramíneas, contenção hidráulica (lago) e equipamentos recreativos e esportivos, características atrativas para o público. É de uso cole- tivo e muito frequentado pela população, que participa dos projetos culturais e desportivos, a exemplo: atividades físicas (dança) e desportivas gratuitas, isso é possível devido à infraestrutura do parque, destacando-se suas duas quadras poliesportivas. O Parque Sabiá tornou-se um referencial nas áreas de fins ecológicos e bem -estar humano, haja vista a preservação da biodiversidade, lazer e desporto na cidade de Cacoal.

Outra área importante para a comunidade cacoalense é a Praça Municipal Governador Jorge Teixeira (Tabela 3), considerada a maior praça do município, com $9.604 \mathrm{~m}^{2}$. Localizada no centro da cidade, a área é edificada, mas com $70 \%$ de cobertura vegetal arbórea. Destina-se ao lazer e eventos culturais de uso coletivo pela população e visitantes, é formada de fonte de água artificial, biblioteca, equipamentos públicos recreativos e desportivos. A vegetação da praça encontra-se em bom estado de preservação ambiental, ainda assim necessita de plantio de novas espécies de árvores para proporcionar melhor conforto ambiental aos visitantes. 


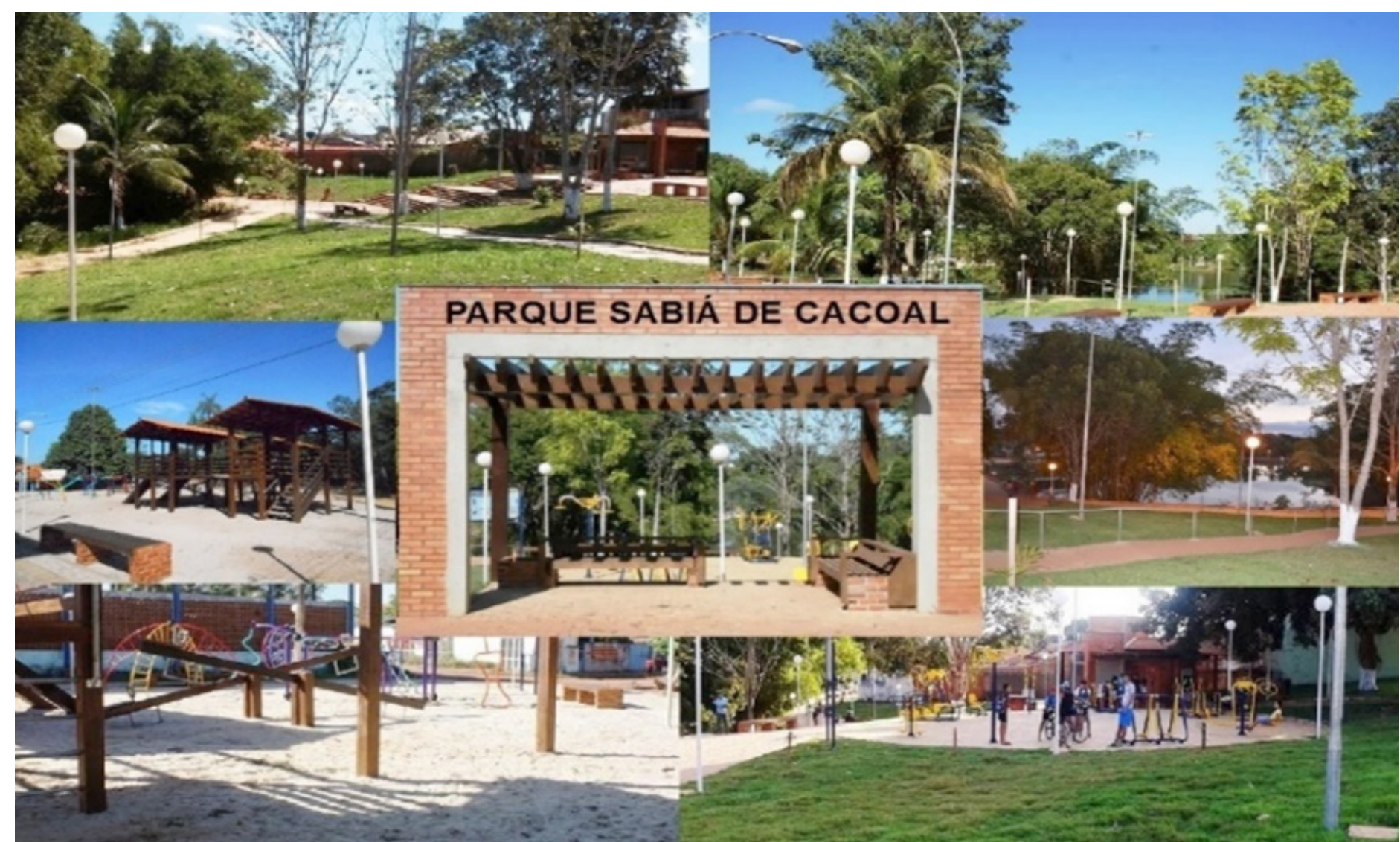

Figura 6 - Parque Ecológico Sabiá. Fonte: elaborado pelo autor, 2016

\section{Discussões}

Este estudo mostrou, a nível de ordenamento municipal, que os limites territoriais do perímetro urbano da cidade de Cacoal são definidos pela Secretaria de Planejamento, por meio do Plano Diretor Municipal, e que os setores censitários estabelecidos pelo (IBGE), bem como o censo populacional por bairros da cidade, abrangem somente os 19 bairros mais antigos, o que dificulta a obtenção de dados estatísticos, como a densidade populacional e índices de Áreas Verdes por bairro da cidade, dificuldade também relatada por Lucon et al., (2013). Sem embargo, a metodologia empregada, fundamentada na análise quanti-qualitativa das Áreas Verdes, possibilitou a identificação e caracterização delas, da mesma maneira que os índices de qualidade ambiental, reve- 
lando-se satisfatória, uma vez que o objetivo do trabalho, formulado inicialmente, foi alcançado.

Das 24 Áreas Verdes públicas, somente nove foram registradas nos bairros antigos. Identificou-se que há 15 bairros com ausência de Áreas Verdes (Tabela 2), apenas com arborização viária, possuindo irregularidades por terem sido implantados sem planejamento adequado (DE ALMEIDA \& BARBOSA, 2010), além de não contemplarem todas as avenidas e ruas. A cidade possui apenas seis (06) Áreas Verdes utilizáveis (destinadas ao uso coletivo pela população), representadas por um Parque Ecológico (Parque Sabiá) e cinco Praças Municipais (Tabela 4), todavia, há 18 Áreas de Proteção Ambiental (APA) para fins ecológicos.

\subsection{Percentagens e índices de áreas verdes}

Os indicadores ambientais utilizados neste estudo foram eficazes para avaliar o status das respectivas Áreas Verdes públicas da cidade de Cacoal. Percebeu-se que a ampliação do perímetro urbano (Figura 1), de certa forma, contribuiu para o surgimento de novas Áreas Verdes, tendo em conta a existência dessas na maioria dos novos bairros (Figura 2), resultado dos critérios adotados pelo poder público para a aprovação dos projetos de loteamentos, que passa a exigir do loteador a destinação de $5 \%$ do loteamento para Áreas Verdes públicas, respeitando as observações da presença de vegetação nativa e recursos hídricos estabelecidas no Plano Diretor Municipal, visando a conservação dos ecossistemas urbanos de Cacoal.

Cacoal teve seu Plano Diretor Municipal implantado somente em 2006, até esse período, a cidade era formada por 19 bairros, $80 \%$ com ausência de Áreas Verdes (Figura 3). O crescimento expressivo nos últimos anos, movido pela especulação imobiliária e ausência de fiscalização, comprometeu os cuidados com a vegetação urbana. Algumas Áreas Verdes foram eliminadas para construções de moradias, é o caso do bairro Vila Verde, onde grande parte das Áreas Verdes passaram por forte interferência antrópica (Figura 5), como desflorestamento e queimadas. Ao todo, 64,34\% das Áreas Verdes registradas estão degradadas, esse agravante interfere na qualidade ambiental da cidade, em desacordo com a legislação federal e municipal vigente.

Embora os percentuais de Áreas Verdes (PAV) por bairros tenham indicado elevação satisfatória para o bairro Nova Esperança (Tabela 2 ), em consonância com os parâmetros de qualidade ambiental propostos por Luz \& Rodrigues (2012), que sugerem o índice de 30 $\%$ de cobertura vegetal nas áreas urbanas, para os demais bairros e regiões (Tabela 3) os percentuais foram insuficientes e comprometem a qualidade ambiental. É necessário ressaltar que as Áreas Verdes Urbanas são bastante fragmentadas e não estão distribuídas de forma homogênea na paisagem urbana, a exemplo da região oeste (Tabela 3). Sendo assim, entende-se que o cálculo simplificado de percentagem e índice de Áreas Verdes, considerando apenas as quantidades referentes à extensão das Áreas Verdes e ao número de habitantes, pode conduzir a uma homogeneização incorreta da informação espacial.

A avaliação das condições ambientais (Tabela 2, Figura 4) mostra que os bairros com maiores índices de Áreas Verdes por bairro (IAVPB) foram: Vila Verde $-500 \mathrm{~m}^{2}$, Parque Alvorada - $173 \mathrm{~m}^{2}$, Bairro Buritis - $149 \mathrm{~m}^{2}$, Jardim Europa - $89 \mathrm{~m}^{2}$, Nova Esperança - 59,59 $\mathrm{m}^{2}$, e Jardim Eldorado - $53 \mathrm{~m}^{2}$. Enfatiza-se que esses bairros, maiormente, são loteamentos novos, com $80 \%$ dos lotes vazios, e esses índices poderão ser alterados futuramente, conforme o aumento do número de habitantes locais.

No contexto geral, considerando o percentual de Áreas Verdes (PAV) de 0,11\% e o índice de Área Verde (IAV) de $6,83 \mathrm{~m}^{2}$ por habitante, entende-se que, mesmo que tenham sido incorporadas novas áreas que apresentem características de Áreas Verdes à área urbana oficial da cidade, a quantidade de Áreas Verdes disponíveis por habitante ainda é insuficiente, particularmente nos bairros antigos. As áreas urbanas totalmente vazias, sem nenhuma ou com menos de $5 \%$ de cobertura vegetal, são áreas nomeadas de "deserto florístico", nas quais pode existir elevada temperatura e desconforto térmico (NUCCl, 2008), o que requer mais atenção sobre o sistema de gestão e preservação das Áreas Verdes da cidade de Cacoal, pensando no bem-estar humano, levando em consideração suas características climáticas, típicas de região da Amazônia 
Legal. A falta de Áreas Verdes é prejudicial à cidade em virtude do aumento da poluição e degradação ambiental generalizada provocados pelas ações antrópicas (LIMA NETO et al., 2007), ademais das alterações climáticas.

Notou-se uma defasagem de áreas com funções recreativas na cidade, das seis (06) áreas registradas, somente duas passaram por processo de revitalização recentemente, sendo o Parque Ecológico Sabiá e a Praça do Bairro Novo Cacoal, construída em 2013. O índice e quantidade de Áreas Verdes utilizáveis na cidade é muito baixo (Tabela 4), comparado à quantidade de Áreas Verdes registrada. Das 24 Áreas Verdes existentes, apenas 25\% oferece condições de uso coletivo pela população, o que requer maior esforço por parte dos governantes na criação de estratégias que visem aumentar a oferta de Áreas Verdes e conforto ambiental.

Também se concluiu que a composição vegetal das referidas Áreas Verdes destinadas ao lazer e desporto apresenta pouca variedade de espécies, as mais comuns são das famílias Chrysobalanaceae (Oiti), Moraceae (Fícus), Palmae, Euterpe oleracea (Açaí), Roystonea oleracea (Palmeira imperial), Poaceae, Bambusa vulgaris (Bambu), Bignoniáceas, Tabebuia chrysotricha (Ipê-amarelo). Essas espécies têm bom potencial ornamental, entretanto, exigem cuidados quanto à escolha do local para plantio e manutenção, segundo (DE ALMEIDA \& BARBOSA, 2010).

As principais Áreas Verdes utilizadas, de maior relevância na cidade: Parque Ecológico Sabiá (Figura 6) e a Praça Municipal Governador Jorge Teixeira, estão em boas condições ambientais, assegurando benefícios e qualidade ambiental para a comunidade local - conforto térmico, atenuação da poluição do ar, sonora e visual e abrigo para fauna (NUCCI, 2001; BARGOS, 2010). De modo igual, Áreas Verdes desempenham papel fundamental na melhoria da qualidade de vida dos habitantes, por estarem intimamente ligadas ao lazer e recreação, além das práticas desportivas da população, atividades que acontecem no Parque Ecológico Sabiá de Cacoal/CE.

A importância das Áreas Verdes Urbanas é reafirmada em estudos por diversos pesquisadores, como: Andrade (2001); Buccheri Filho \& Nucci (2006); Cavalheiro \& Del Picchia (1992); Costa \& Colesanti
(2011); Loboda \& De Angelis, (2005); Nucci (2008); Matias et al., (2008), os quais tratam da abordagem conceitual desses espaços, sua importância para a qualidade de vida, agindo simultaneamente nos aspectos físico e psicológico do ser humano, somando-se às suas funções ambientais, sociais e estéticas, e à sua capacidade de amenizar a gama de propriedades negativas da urbanização, reconhecendo as Áreas Verdes como elementos vitais e essenciais da cidade.

Nesse cenário, torna-se cada vez mais indispensável o conhecimento dessas áreas no ambiente urbano, sobretudo pelas funções que assumem na melhoria das condições ambientais e na saúde da população, na diversificação da paisagem e nos aspectos paisagísticos. É necessário, também, o desenvolvimento de mais estudos para obter um diagnóstico mais completo do real cenário das Áreas Verdes nas milhares de cidades brasileiras.

Os resultados de estudos realizados em algumas cidades brasileiras demonstram que os Índices de Áreas Verdes são relativamente baixos, à exceção da cidade de Curitiba (PR), com 9,55 m² de Área Verde/habitante (considerada a cidade ecológica do Brasil), e Goiânia (GO), com 100,25 $\mathrm{m}^{2}$ de Área Verde/habitante (OLIVEIRA, 1996). No entanto, os resultados dos Índices de Áreas Verdes por Bairro (IAV/PB) da cidade de Cacoal mostraram-se muito elevados para treze (13) bairros, com variações entre (15 a 500) de Área Verde/ habitante (Tabela 2 e Figuras 3-4).

No contexto geral, o resultado de IAV da cidade de Cacoal revelouse superior, com $6,83 \mathrm{~m}^{2}$ por habitante, em relação aos resultados de IAV em outras cidades, por exemplo: Bauru (SP), com 6,29 $\mathrm{m}^{2}$ de Área Verde/hab. (OLIVEIRA et al.,1999; JESUS \& BRAGA, 2005); Vinhedo (SP), com 2,19 $\mathrm{m}^{2}$ de Área Verde/hab. (HARDER et al., 2006); Lavras (MG), com 0,34 $\mathrm{m}^{2}$ de Área Verde/hab. (CARVALHO, 2001) e Piracicaba (SP), com 2,2 $\mathrm{m}^{2}$ de Área Verde/hab. (LIMA, 1993). As diferenças entre os valores de IAV para as diferentes cidades decorre, mormente, dos critérios para categorização das chamadas Áreas Verdes Urbanas e das metodologias utilizadas para o seu cálculo.

Tanto os PAV quanto os IAV, assim como os IAVPB e os IPAAV usados neste estudo da cidade de Cacoal, são fundamentais para o 
planejamento urbano, pois, a partir deles, permite-se observar a dinâmica populacional e sua relação com as Áreas Verdes e as condições ambientais na área urbanizada, possibilitando, ao poder público, garantir áreas públicas para atendimento das demandas por Áreas Verdes e equipamentos urbanos diversos.

Desse modo, este estudo pode colaborar para a elaboração de propostas de políticas públicas que objetivem regularizar e estabelecer medidas para melhorias do planejamento urbano, observando os projetos de infraestrutura e a reorganização do espaço urbano inserido no Plano Diretor, diretriz que assegura a criação e preservação de Áreas Verdes Urbanas, que desempenham funções importantes e essenciais para a qualidade de vida no ambiente urbano da cidade de Cacoal.

\section{Conclusão}

O estudo das Áreas Verdes Urbanas proporcionou obter um diagnóstico das Áreas Verdes Urbanas de Cacoal/Rondônia, possibilitando a construção de um cenário do desenvolvimento sustentável da cidade no que refere às Áreas Verdes, onde o IVA corresponde a $6,83 \mathrm{~m}^{2}$. Em comparação ao espaço habitado e às Áreas Verdes presentes, obteve-se PAV de $0,11 \%$, o que caracteriza um gargalo na gestão municipal em cumprimento da legislação ambiental, porque demonstra que o fato da existência e acessibilidade a essas Áreas Verdes não é suficiente para que suas funções sejam exercidas adequadamente, comprometendo, assim, a qualidade ambiental na cidade, em especial o desconforto térmico que, por sua vez, pode afetar a saúde dos cacoalenses.

Quanto ao índice de Áreas Verdes por região, encontra-se com problema de distribuição espacial, a região oeste apresenta maior índice, de 3,59\%, e também maior quantidade de bairros e Áreas Verdes em relação às outras regiões. A região com maior adensamento populacional possui menor quantidade de Áreas Verdes. Porém, os bairros com maiores quantidades de Áreas Verdes concentram maior percentual de degradação dessas áreas (por exemplo, o bairro Vila Verde). Isso está relacionado ao fato de esses espaços, anteriormente rurais, terem sido desflorestados para a formação de pastagens. Com o crescimento expressivo da cidade, essas respectivas áreas passaram a incorporar a zona de expansão urbana do município de Cacoal, além de outras áreas, com florestas nativas, que foram suprimidas, transformadas em loteamentos urbanos.

Os resultados dos índices chamam atenção para a forma de planejamento e gestão ambiental da cidade de Cacoal, no que diz respeito aos cuidados com espaços verdes urbanos, podendo estar relacionados à falta de um plano de vegetação urbana com diretrizes, visando à criação e preservação das eventuais Áreas Verdes. A falta de consenso quanto à preservação das Áreas Verdes dificulta o mapeamento, a classificação e avaliação dos índices. A legislação não é aplicada como deveria e as Áreas Verdes não recebem os devidos cuidados necessários para manutenção e equilíbrio ambiental urbano. Mesmo assim, a cidade de Cacoal dispõe de uma gama de Áreas Verdes Urbanas relevantes, algumas em fase de reflorestação que, futuramente, poderão elevar significativamente os índices de qualidade ambiental.

\section{ReferênCIAS Bibliográficas}

ANDRADE, R. V. O processo de produção dos parques e bosques públicos de Curitiba (Dissertação de Mestrado). Setor de Ciências da Terra, Universidade Federal do Paraná, 1-120, 2001.

ANDRADE, F. A. V. (In) Sustentabilidade urbana e impactos socioambientais: uma abordagem acerca da ocupação humana desordenada no espaço urbano. Contribuciones a las Ciencias Sociales, 13(2), 1-16, 2013. https://doi.org/10.17563/ somanlu.v13i2.4020

BARGOS, D. C. Mapeamento e análise das áreas verdes urbanas como indicador da qualidade ambiental urbana=estudo de caso de Paulínia-SP (Dissertação de mestrado). qualicade ambiental ur a p. $1-151,2010$

BERTRAND, G., \& BERTRAND, C. Uma geografia transversal e de travessias: o meio ambiente através dos territórios e das temporalidades. Maringá: Massoni, p. 290-291, 2007.

BRASIL. Constituição da República Federativa do Brasil, de 5 de outubro de 1988. Brasília: Senado Federal, Coordenação de Edições Técnicas, p. 1-496, 2016. Recuperado em 20 de abril de 2016, de www.senado.gov.br.

BRASIL. Estatuto das Cidades (Lei n. 10.257/2001) de 10 de julho de 2001. 3. ed. -

Brasília: Senado Federal, Subsecretaria de Edições Técnicas, p. 1-102, 2008 Recuperado em 20 de abril de 2016, de www.cidades.gov.br. 
BRASIL. Resolução CONAMA no 369 de 28/03/2006 do Conselho Nacional do Meio Ambiente-CONAMA. Brasília: Diário Oficial da União, Sessão 061, p. 150-151, 2006. Recuperado em 20 de abril de 2016, de www.mma.gov.br/conama.

BRASIL. Ministério do Planejamento. Guia Referencial para Medição de Desempenho e Manual para construção de indicadores, Brasília. 2009. Recuperado em 20 de abril de 2016, de http://www.gespublica.gov.br.

BRASIL. Ministério do Meio Ambiente. Plano de Trabalho para Execução das Atividades do GTI e Definição e Sistematização de Indicadores Ambientais e de Desenvolvimento Sustentável. Departamento de Gestão Estratégica, Comitê de Tecnologia da Informação. Brasília, 2011. Recuperado em 20 de abril de 2016, de http://www.gespublica.gov.br.

BRASIL. Lei no 12.651 de 25 de maio de 2012 do Código Florestal Brasileiro. Dispõe sobre a proteção da vegetação nativa. Brasília: Diário Oficial da União, Seção 1, 2012. Recuperado em 20 de abril de 2016, de http://www.planalto.gov.br/ccivil_03/LEIS/ L4771.htm.

BORTOLETO, S., SILVA FILHO, D. F., \& LIMA, A. M. L. P. Prioridades de manejo para a arborização viária da estância de Águas de São Pedro-SP, por setores. Revista da Sociedade Brasileira de Arborização Urbana, 1(1), p. 62-73, 2006.

http://dx.doi.org/10.5380/revsbau.v1i1.66499.

BUCCHERI FILHO, A. T., \& NUCCI, J. C. Espaços livres, áreas verdes e cobertura vegetal no bairro Alto da XV, Curitiba/PR. Revista do departamento de Geografia, 18, 48-59, 2006.

CAPORUSSO, D., \& MATIAS, L. F. Áreas verdes urbanas: avaliação e proposta conceitual. In Anais do VIII Seminário de Pós-graduação em Geografia da UNESP. Rio Claro-São Paulo: UNESP, p.1-17, 2008

18 CARVALHO, L. D. Áreas verdes da cidade de Lavras/MG: caracterização, usos e necessidades (Dissertação de Mestrado). Universidade Federal de Lavras-Minas Gerais, p. 1-115, 2001.

CAVALHEIRO, F., \& DEL PICCHIA, P. C. D. (1992). Áreas verdes: conceitos, objetivos e diretrizes para o planejamento. In Anais do Encontro Nacional sobre Arborização Urbana (p. 29-38). Vitória - Espírito Santo.

COSTA, R. G. S., \& COLESANTI, M. M. A contribuição da percepção ambiental nos estudos das áreas verdes. Raega-O Espaço Geográfico em Análise, 238-251, 2011. http://dx.doi.org/10.5380/raega.v22i0.21774

DE ALMEIDA, J. R D., \& BARBOSA, C. G. Diagnóstico da arborização urbana da cidade de Cacoal-RO. Revista da Sociedade Brasileira de Arborização Urbana, 5 (1), p. 61-81, 2010. http://dx.doi.org/10.5380/revsbau.v5i1.66239

DE ALMEIDA, J. R. Urbanização em área de risco: diagnóstico dos impactos socioambientais do rio pirarara no Município de Cacoal Rondônia. Revista Presença Geográfica, 3(2), p. 25-44, 2016. https://doi.org/10.36026/rpgeo.v3i2.2034

DE JESUS, S. C., \& BRAGA, R. Análise espacial das áreas verdes urbanas da estância de áquas de São Pedro-SP. Caminhos de Geografia, 6 (16), p. 207 - 224, 2005.

DE LIMA NETO, E. M., RESENDE, W. X., SENA, M. G. D., \& MELO, R. Análise das áreas verdes das praças do bairro centro e principais avenidas da cidade de Aracaju-SE. Revista da Sociedade Brasileira de Arborização Urbana, 2 (1), p. 17-33, 2007.

HARDER, I. C. F., RIBEIRO, R. D. C. S., \& TAVARES, A. R. Índices de área verde e cobertura vegetal para as praças do município de Vinhedo, SP. Revista Árvore, 30 (2) p. 277-282, 2006.

IBGE - Instituto Brasileiro de Geografia e Estatística. Censo Demográfico. Rio de Janeiro, 2010. Recuperado em 10 de maio de 2015, de www.ibge.gov.br/cidades.
IBGE - Instituto Brasileiro de Geografia e Estatística. Estimativa da população. Rio de Janeiro, 2015. Recuperado em 10 de maio de 2015, de www.ibge.gov.br/cidades.

INPE - Instituto Nacional de Pesquisas Espaciais. Imagens de Satélite, 2016. Recuperado em 10 de maio de 2015, de www.dpi.inpe.br/prodesmunipal.

LIMA, V., \& AMORIM, M. C. D. C. T. A importância das áreas verdes para a qualidade ambiental das cidades. Revista Formação (Online), 1(13), p. 139-165, 2006.

LIMA, A. M. L. P. Análise da arborização viária na área central e em seu entorno (Tese de Doutorado). Escola Superior de Agronomia "Luiz de Queiroz", Universidade de São Paulo - USP, Piracicaba-SP, 1993.

LOBODA, C. R., \& DE ANGELIS, B. L. D. Áreas verdes públicas urbanas: conceitos, usos e funções. Ambiência - Revista do Centro de Ciências Agrárias e Ambientais, 1(1), p. 125-139, 2005.

LUCON, T. N., PRADO FILHO, J. F. D., \& SOBREIRA, F. G. Índice e percentual de áreas verdes para o perímetro urbano de Ouro Preto-MG. Revista da Sociedade Brasileira de Arborização Urbana, REVSBAU, (8), p. 63-78, 2013. http://dx.doi.org/10.5380/revsbau. v8i3.66430.

LUZ, L. M. D., \& RODRIGUES, J. E. C. Atlas de áreas verdes da cidade de Belém. (1 ${ }^{\mathrm{a}} \mathrm{ed}$, Vol. 1). Belém: GAPTA/UFPA, p. 1-41, 2012. http://livroaberto.ufpa.br/jspui/handle/prefix.

MATIAS, L. F., \& CAPORUSSO, D. Áreas verdes urbanas: avaliação conceitual e metodológica a partir do estudo de caso na cidade de Paulínia-São Paulo, Brasil. Universidade Estadual de Campinas - UNICAMP, Campinas-SP, p. 1-139, 2009.

MATIAS, L. F., CARVALHO, J., MARGUTI, B., \& FARIAS, F. Mapeamento do uso da terra na cidade de Paulínia (SP): desenvolvimento de aspectos metodológicos para detalhamento intra-urbano. In Anais do XV ENCONTRO NACIONAL DE GEÓGRAFOS, São Paulo, p. 1-2, 2008.

MORERO, A. M., DOS SANTOS, R. F., \& FIDALGO, E. C. C. Planejamento ambiental de áreas verdes: Estudo de caso em Campinas/SP. Embrapa Solos-Artigo em periódico indexado (ALICE) 19 (1), p.19-30, 2007.

NUCCI, J. C. Qualidade ambiental \& adensamento urbano: um estudo de ecologia e planejamento da paisagem aplicado ao distrito de Santa Cecília (MSP). São Paulo: $1^{\text {a }}$ Edição Humanitas/FFLCH/USP, p. 1- 235, 2001.

NUCCl, J. C. Qualidade ambiental e adensamento urbano: um estudo de ecologia e planejamento da paisagem aplicado ao distrito de Santa Cecília (MSP). Curitiba: O autor, 2a Edição, p. 1-150, 2008.

OLIVEIRA, C. H. D. Planejamento ambiental na cidade de São Carlos (SP) com ênfase nas áreas públicas e áreas verdes diagnóstico e propostas (Dissertação de Mestrado). Universidade Federal de São Carlos. UFSCAR, São Carlos, p. 1-181, 1996.

OLIVEIRA, C. H., SANTOS, J. E., \& PIRES, J. S. R. Indicadores de arborização urbana da cidade de São Carlos (SP) com o uso do SIG-IDRISI. Brazilian Journal of Ecology, 3(1), p.1-9, 1999

PASQUAL, M. O. A., \& FACHINI, M. P. Espaço verde urbano-importância na dinâmica da paisagem. Produção didático-pedagógica do Programa de Desenvolvimento Educacional (PDE). Secretaria de Estado da Educação do Paraná (SEED). Maringá-Paraná, p.1-26, 2008 PMC-Prefeitura Municipal de Cacoal. Lei Municipal 2016/PMC. Institui o Plano Diretor do Município e Desenvolvimento Urbano no Município de Cacoal, 2006. Recuperado em 10 de abril de 2016, de www.cacoal.ro.gov.br.

RODRIGUES, J. E. C., \& LUZ, L. Mapeamento da cobertura vegetal da Área Central do municipio de Belem PA, atraves de sensores remotos de base orbital (sensor 
TM, LANDSAT 5 e sensor CCD, CBERS 2). In Anais do XIII Simpósio Brasileiro de Sensoriamento Remoto, Florianópolis, Brasil. p.1063-1070, 2007.

SAMPAIO, D. T. Sustentabilidade urbana: conceitos e controvérsias. In anais do ELECS,

- $V$ Encontro Nacional e III Encontro Latino-Americano sobre Edificações e Comunidades Sustentáveis, Recife, 5, p. 1-10, 2009.

SEMPLAN-Secretaria Municipal de Planejamento. Zoneamentos urbano e ordenamento geográfico. Departamento de Engenharia da Prefeitura Municipal de Cacoal-RO, 2016.

SBAU - Sociedade Brasileira De Arborização Urbana. A Carta de Londrina e Ibiporã.

Boletim da Sociedade Brasileira de Arborização Urbana. Botucatu-SP, Ano III, 3 (5), p.

1-3, 1996.

SOUZA, M. R., SCOPEL, I. S., \& MARTINS, A. P. Áreas verdes do sítio urbano de Jataí (GO). Caminhos de Geografia, Uberlândia, MG 15(51), p. 181-198, 2014.

VAN BELLEN, H. M. Indicadores de Sustentabilidade: Uma análise comparativa (2 ${ }^{\mathrm{a}}$ ed.

Vol. 1). Rio de Janeiro: Editora FGV, p. 1-256, 2006.

Juscidalva Rodrigues de Almeida

Universidade Federal de Rondônia (UNIR)

Campus - BR 364, Km 9,5. CEP: 76801-059 - Porto Velho - Rondônia

https://orcid.org/0000-0003-1048-6094

biologa.2008@hotmail.com

Notas do Editor:

Data de submissão: 14/03/2021

Data de Aceite: 18/06/2021

Revisão: 